庭の理念 一 アレホ・カルペンティエルにおける

オルテガ思想の影慜に関する試論

杉浦 勉

読者は自分が悹ガラスを通して庭を䁬めているところを想像してはしい。 われわれの目は視線が悹ガラスには止まらずに通り越して、花や茂みに留 まるように調整される。視線の対象が庭であり、そこまで視線が向けられ た以上、悹は目に入らないし、視線はそれを通過して、その存在を意識す ることもない。ガラスが透明であればあるほど、それは見えにくくなる。 しかし、あえて庭を意識せず、視線を引いて、ガラスにすえることは可能 である。すると庭は眼前から消え、ガラスに貼り付いたような、ぼやけた その色の塊しか見えなくなる。したがって、庭を見ることと悹ガラスを見 ることは、ふたつの両立不可能な行為なのである。(Imagínese el lector que estamos mirando un jardín al través del vidrio de una ventana. Nuestros ojos se acomodarán de suerte que el rayo de la visión penetre el vidrio, sin detenerse en él, y vaya a prenderse en las flores y frondas. Como la meta de la visión es el jardín y hasta él va lanzado el rayo visual, no veremos el vidrio, pasará nuestra mirada a su través, sin percibirlo. Cuanto más puro sea el cris tal menos lo veremos. Pero luego, haciendo un esfuerzo, podemos desentendernos del jardín y, retrayendo el rayo ocular, detenerlo en el vidrio. Entonces el jardín desaparece a nustros ojos y de él sólo vemos unas masas de color confusas que parecen pegadas al cristal. Por tanto, ver el jardín y ver el vidrio de la ventana son dos operaciones incompatibles. $)^{1)}$ 
オルテガ・イ・ガセーが一九二五年に発表した論考「芸術の脱人間化」は、 当時勃興しつつあった新しい芸術の運動に対して強力な支持を表明し、その担 い手たちに理論的な基礎を提供する意味を持った 2)。オルテガがこの論文のな かで企てている最大の主題は、<脱人間化>というかれの用語に象徽されるよ うに、芸術作品を人間的な関心から解放することにあった。たとえばオルテガ はのべている「芸術作品があるいは言及し、描写するような人間の運命に一喜 一㚆することは、真の芸術的享受とはおよそ異なっている。更に作品が人間的 なものに対して抱くそうした関心は、原則として、厳密な美の快楽とは相容れ ないのである。（Alegrarse o sufrir con los destinos humanos que, tal vez, la obra de arte nos refiere o presenta, es cosa muy diferente del verdadero goce artístico. Más aún: esa ocupación con lo humano de la obra es, en principio, incompatible con la estricta fruición estéti(a.)」3) オルテガのこうした言説の動機になっているのは、具体的にいえば 十九世紀に全盛をきわめたロマン主義やリアリズムの芸術に向けた批判、否定 であるが、その問題設定は実はより根本的な知的背景を有する。このことをオ ルテガ哲学の理論的展開からいえば、この作品は純伜理性の廃棄から出発した 生理性論が最終段階に入り、次の歴史理性論へ移行する時期に位置し、そこで リアリズムに代表される旧芸術において影著な生を芸術へ従属させる志向を転 倒し、逆に芸術による生への従属、すなわち芸術のための芸術という理念がた てられることになる ${ }^{4)}$ 。この時期のオルテガが文化や芸術の理論的考察に精力 を注ぎ、の哲学体系にとって美学理論の構築が重要な役割を担ったのは以上 の事情に由来する ${ }^{5)}$ 。

芸術作品、今日的な表現によるなら広義のテクストにおける人間的なものと は、「われわれの日常世界を構成する諸要素の全体」6)であるとオルテガはいう。 だがこの定義はわれわれが日常的に経唋する生活世界の現実（「生きられる現 実」）に他ならず、オルテガによれば、われわれが対象から距離をとり、対象 を疑視の主題とすることによって、もう一方の現実（「視される現実」）が 
現われる。この現実こそがわれわれの人間的な現実とは異質な、そして日常的 な生活世界から独立したテクストの現実なのであり、ここにオルテガ美学の基 本的命題である芸術の非現実性が存する。われわれが現実について把握するの は、そこから形成し得る観念でしかなくしたがって現実と観念とはまったく異 質なものである。リアリズムとは両者を混同し、現実の観念化を志向する企て であるが、観念が非現寒である以上、必要なことは観念を非現実のままに志向 し、現実の客観的な模写という欺瞒を放裹して、いわば非現実を非現実として 現実化することである。これがく脱人間化 >論の問題構成である7)。

オルテガは問題の論考において、新しい芸術が持つ幾つかの傾向を具体的に 指摘しているが8)、それらは『現代の課題』El tema de nuestro tiempo $(1923)^{9)}$ を中心とする一九二十年代の諸論考のなかで、さまざまな表現やイメ ージを装いながら繰り返し考察された特徵である。これまで見たようなく脱人 間化>論の中心的な主題は、オルテガもいうように10)、芸術創造の到達点では なく出発点であった。なぜならばこの理論でのオルテガの意図は明らかにく脱 人間化>自体によりも、それを惹起するはずの 視点の主観性やテクストの自 己言及性の強調にあったからである。そしてこれらのオルテガの指摘は、純 玤詩や純粋小説といったその同時代の企てから、絶対者としての作者の地位 を崩壊せしめたサルトルのモーリヤック論を経て、後に触れる現在のメタフィ クション論に至る二十世紀文学の思湖を展望すれば、篤くべき射程を備えた洞 察だということができる。これらの指摘に比べると芸術の遊戯性や轻みなどの 議論は、オルテガ思想の展開のうえでは独自の位置を占めるとはいえ、今日で はさしたる関心もひかないようにおもわれる。

そして冒頭に掲げた庭と空ガラスのイメージこそは、オルテガのく脱人間 化>論の核心を成す隠喻として、しばしば言及されるものである。ここでは庭 が対象という現実を、㝒ガラスがテクストという非現実を表わしている。更 にペレス・フィルマーによれば、この隠喻が照明するのは、非・美的な快楽と 美的な快楽との相異、不純な芸術と純䎦な芸術との相異、人間的な問題を表現 することで世界に開かれてゆく芸術と自己言及的な芸術との相異であるとい う11)。この隐哴が重要だという根敃は三つある。第一は今までのべてきたよう 
に、それが現実（「作品で言及される人間的現実」）と芸術作品というテクス トとを明確に分離して設定したことである。この分離はさきにのべた現実と锶 念の関係に即していえば、両者を隔てる絶対的距離に等しい。芸術家は人間的 な現害という対象ではなく、主钼に内在する世界、すなわち钼念に目を向けね ばならないのである。第二はこのような現実とテクストの分離を必然たらしめ る視点の存在である。オルテガ美学における梘点の問題は、周知のように「美 術における視点について』Sobre el punto de vista en las artes (1924) と いう論文に集約されているが(『現代の課題」最終章はこの問題をめぐるより 抽象度の高い考察である)、その棌嫄は有名なパースペクティウ論に求められ る12)。「ドン・キホーテをめぐる省察』においてオルテガは、「世界の決定的 実在は．..... パースペクティウである」との命題を提出し、パースペクティ ウこそ現実の条件であり、その真実に接近する可能性であることを示した。庭 と空ガラスの隠喻は、日常世界の現実とテクストという非見実との相対性、両 立不能性を企てたものであるが、それが成立するのは芸術の歴史を通貫する梘 点の移行という基本原理が存在するからであり、視点の関心が客体から主体に 向かい、したがって人間的現実からテクストに向かうという自己言及化の過程 を前提しているからである。オルテガのパースペクティウ論はこうして梘点論 と連動し、テクストの自己言及化の必然を高らかに宣言する。そして第三は、 ここで示された庭というイメージが決して隠喻のための隠喻ではないというこ とである。オルテガは庭というイメージを問題の論文の続編を成す「小説の理 念」においても採用しており、その「庭が描かれた絵を庭で見る」というイメ ージにおいて ${ }^{13)}$ 前者の庭がテクストの、後者の庭が現実の隐喻であることは 自明であろう。この隐喻は小説が現実から断ち切られた「ヘルメス的な領域」 でなければ、描かれたテクストは現実化してしまい、テクストとしての重要性 も強度も失う例として示されている。『芸術の脱人間化』における庭はガラス 悹と対置されることによって現実とテクストとの非対称性を表わし、ここでは 描かれた庭と胃実の庭という対置が両者の対称性を表わしているとペレス・ フィルマーは指摘する14)。けれどここでほんとうに重要なのは、オルテガが好 んで用いる庭というイメージの本質であり、この隠崳の思想的な必然性だとい 
うべきである。

オルテガ・イ・ガセー 一そして自ら創刊した維誌「西欧評論」一が初期の カルペンティエルや、かれの参加した前衛的な芸術運動に大きな影篦を与えた ということを ゴンサーレス・エチェバリーアはのべている。|オルテガはスペ イン語世界に、「芸術の脱人間化」において影著なヨーロッパの前街䒧術の㷫 烈な評価をもたらしたが、更に重姴なことは、かれが新しい芸術の鬼力的な哲 学的正当化と、加えて自民族中心主義を否定する文化の蔇念挰出したことで あった。 (Ortega brought to the Spanish-speaking world an onthusiastic appraisal of the European avant-garde that is manifest in "The Dehumanization of the Art, but more importantly he furnished an appealing philosophical justification for the new art, together with a conception of culture that denied ethnocentrism.)」占) オルテガが「自民族中心 主義を否定する文化の摡念」を構想していたことは、少なくともこの時期のか れの論考にみられる東洋人や「エキゾチックな芸術」に関する言及から判断す ると、きわめて疑わしいといわねばなるまい16) しかしオルテガのく脱人間 化>論が、「不人気」に晒されていた若い前衛芸術の担い手たちを鼓舞し、かれ らに理論的な方向付けを与えたことは想像に短くない。問題の論考のなかでオ ルテガは再三にわたって新しい芸術家を攡荄し、その末尾では今後の成果に向 けて期待感さえ表明しているからだ。後にカルペンティエルも記すように尚、 オルテガが文化や芸術の方向付けというこうした文脈で若い世代に及ぼした影 整は巨大であった。

く脱人間化＞論をはじめとする二十年代のオルテガの美学理論一般に最大の 影㫪を受けた作家はベンハミン・ハルネスであった。ポール・イリーによれば ハルネスの作品は、「現実からその現実的内容を拿い去り、一方でその残辌を 胃実の単なる相似物とする」という意味でのく脱人間化 $>$ の体現であり、同時 に際立った特徽として、「主人公の個性の欠如」と「高度に抽象的、理知的な 
言語の使用」を持つという ${ }^{18)}$ 。イリーの研究の対象となったハルネスの小説 「無人の狂気と死』Locura y muerte de nadie (1929) は、ペレス・フィルマ 一やロバート・スパイアーズらによる新しい論考鼻を喚起した作品であるが、 この背景には明らかに近年隆盛するメタフィクション論への関心がある。フィ クションのフィクション性を問い、文学を文学たらしめる根拠を探るメタフィ クション論の素材として、ハルネスの小説は絶好の作品であった。そこでさき に指摘したイリーの幾つかの特徵は、次のように一メタフィクション的に一 いい換えることができる。「主人公の個性の欠如」は「迫真的な登場人物に対 する旧来の小説的関心の消减」であり、代わりに「移ろいやすい、気体のよう な人物」、「カードのように徹底して皮相で、ゆえに人格化のできない人物」が 現われる（オルテガのいう「轻み」）。「理知的な言語の使用」は「プロットも 登場人物もない革新的な小説形式」の志向の結果であり（同じく「生の形象の 忌砗」)、更に『小説の理念』で開陳されたすじの無意味は「語りの意志の衰 弱」として理解できる。要するにハルネスの作品は伝統的な小説形式からの離 反であるという文脈において、く脱人間化 $>$ のぼ忠実な実践なのであり、文 学コードの前景化というテクスト戦略においてはメタフィクション的なのであ る。

ハルネスの作品にみられるこうしたメタフィクション的な特質は、同時代の カルペンティエルの作品、とりわけ『エクエ＝ヤンバ=オー！」Écue-Yamba0!（1933）にも適用できるだろうか20)。キューバに渝入された黒人たちの土俗 的な信仰や宗教儀礼に対する関心から生まれたアフロ・キューバ運動の推進者 であったカルペンティエルが、その実践として構想した唯一の長編小説である この作品の題材は、表面的にもハルネスの作品とは異質である。カルペンティ エルがこの作品で企てた中心的な主題は、アフロ=キューバ的な黒人世界 一 生、宗教、文化一に基く現実と文学的な修辞や文体との融合であった。後者 の表現上の問題として、作者の焦点は登場人物や事件によりも(自然や社会の) 現象や描写にあったという特徵は、なかでも登場人物の人間たちの物象化とい う手法において、<脱人間化>の特質を鲜やかに体現している21)。しかし未 来主義、表現主義、そしてシュルレアリスムといったヨーロッパの前街芸術運 
動の街摮や、伝統的な小説理念の崩壊がもたらした小説自体の危機に由来する こうした表現上の特性は、キューバ内部で進行する政治的、社会的な葛藤につ いて作者が抱いていた問題意識と調和し得たはずがないのは明らかである。こ のことは結果としてテクストに現われた物語上のレウェルの不均質性において 明白であり、記述の対象となった実に多様な現実一ニャニゴと呼ばれる黒人 秘密結社の宗数儀礼から、大統領举の運動を経て、ハリケーン、大火などの 自然の整異に至るまで一がラクスト内部て有機的な閔連性を示さず、ただ点 匠をこらした克明な文体に取领している。『エクエニヤンバ=オー！」がく脱 人間化>論から本質的に隔たっているとおもわれる原因は、こうして異様に不 均質なテクスト空間を造形するに主った方法論上の基礎的な撞着にあった。し かしこの局面で重要なことは、カルペンティエルがアフロ=キューバ運動の位 置から西洋文化とは異なる、したがって自立的な文化理論を構想していたこと と、それによって物語ニテクストと歴史二現実の統一という方法論上の鞛を 企てたことである。初期カルペンティエルの芸術理念に歴史の問題が胚胎して いたことは、この作家が後にたどる軌跡を考えた場合、决定的な事実であった。 いうまでもなくこの事実はオルテガの理論と矛盾し、したがってハルネスの作 品にはとうてい見い出だすことの不可能な特徴である。

ゴンサーレス・エチェバリーアは、オルテガがラテンアメリカに与えた影響 を過大に評価するのは難しいということを綝り返しのべている。かれによれば スペイン語世界に浸透したのはオルテガの思想ばかりでなく、かれの雑誌を通 じて翻訳、紹介された、ドイッ哲学を中心とするヨーロッパの先端的な思想、 芸術でもあった22)。さきの指摘はハルネスとカルペンティエルのほぼ同時代 の作品にみられるく脱人間化>論との関係からも推察できるし、またカルペン ティエル自身のその理論に対する暧昧な態度にもうかがうことができる。『芸 術の脱人間化』から数年後に執筆されたエッセイにおいて、カルペンティエル はシュルレアリスムを中心とした新しい芸術の運動を熱心に論じ、支持しなが らも、そのなかにそれらの運動が「なかば宗教的な知的営為の概念」に負って いるとの疑問を潜ませている ${ }^{23)}$ 。更にほぼ同時期にかれは、ラテンアメリカの 若い芸術家が脱人間化した純执芸術を本気で考えるのは困讙であり、土着の芸 
術こそはあらゆる企てに優先するとの見解を明らかにしているという24) これ らの事実はラテンアメリカの若い芸術家がく脱人間化>論の示した理論的諸前 提には関心を抱きながら、一方でそれらが自らの置かれた文化形成の背景や歴 史的現実に基く芸術創造の理念とは相容れないジレンマを意識していたことを 示唆するようにおもえる。カルペンティエルはく脱人間化 >論が志向するテク ストの新しい現実の必然に魅かれても、自己の属するカリブ世界の歷史的構造 から離脱しようとはしなかった。これは初期カルペンティエルが直面し、その 生淮を通じて葛藤を強いられたジレンマの起源であった。

オルテガが庭のイメージを好んだのは、それがカッコに入れられた現実であ るからだ。周知のようにこの時期のオルテガ哲学はフッサール現象学の強い 影響下にあった。フッサールの構想した現象学理論の基幹を成すのは「現象学 的還元」と呼ばれる操作であり、客観的現実という外部世界を自己の意識に内 在する対象としてのみ把握する方法であった ${ }^{25)}$ 。いかなる現実もなまの現実と してではなく、知覚する主体の「純粋意識」を通じてとらえられねばならず、 同時にその意識の中心たる人間主体は超越的主観性として世界の中心にすえら れる。このような「現象学的還元」が企てるのはまさにその現実の「カッコ入 れ」であり、それによって時空世界はカッコに入れられた対象として、すなわ ち意図された対象として措定されるのである。しかし実にこのために現象学は、 「人間の営為と経験からなる「生活世界」を、伝統的な哲学の残酷な束繧から 解き放つのだというその主張にもかかわらず、世界そのものを捨象した頭だけ の存在に終始した」 ${ }^{26)}$ のである。そして人間の歴史という客観世界に対しては これを捨象した以上、必然的に反歴史的な姿勢をとらざるを得ない。オルテガ の喚起する庭のイメージには、明らかに「現象学的還元」におけるこのような 「カッコ入れ」の操作が值いているといわねばならない。なぜなら庭にはつね に建物が付属しており、その建物のなかには庭を数視する主体、つまりオルテ ガそのひとが位置しているからだ。オルテガの䁖める庭は(花咲き、草匂う)庭 
という現実ではなく、庭の理念なのである。

庭の理念に象徵されるく脱人間化 > 論の反歴史性は、論述においてオルテガ が展開している方法論上の操作からも求められる。オルテガはその末尾におい て、新しい芸術はそれまで注目に值する成果をあげておらず、それらの作品か らその意図を抽出したに留まることを明らかにしている。したがって個々の具 体的な作品に関心を示すこともなく、かれがく脱人間化〉した芸術として指摘 する芸術家は、ドビュッシー、マラルメ、ピランテルロにすぎない。特にオル テガが同時代のスペイン文学に何ら言及していないという事実は、進行中の新 しい芸術の胎動にかれがほんとうに関心を寄せていたか疑問を抱かせる。新し い芸術の意図を抽出するためには、まず個々の具体的な作品に即して不備や問 題を指摘し、それらが破糘や挫折に宿った過程を論理的に説明する必要がある。 こうした作業を捨象したオルテガのく脱人間化＞論は、明らかに現実に根ざし て成立したもの（作品）ではなく、かれ自身が理想と考える新しい芸術の概念 を根拠として構筑されている。要するにオルテガの論じる新しい芸術とは仮構 の概念なのであり、く脱人間化>とはかれの言説がそこへ向けて芸術家たちを 方向付ける理念なのだということができる。

初期の作家カルペンティエルの形成の鍵を成す問題は、かれの参加したアフ ロ=キューバ運動が、主として米国の産業資本による新たな植民地主義に対す る政治闘争に共感していたことであった。『エクエ＝ヤンバ＝オー！』をはじ めとする初期の作品には、独立後まもないキューバに米国の資本家や商品が深 々と浸透していた事実が描写され、かれらに向けた挪揄や皮肉が随所に散見さ れる。米国資本という白人世界に対するこうした態度は、自国の黒人文化の再 認識という方法を通じて、世界史から㻋外された黒人自身の芸術的かつ政治的 な復権と解放を目標としたアフロ=キューバ運動の歴史主義的な理念と、表裏 を構成するといってよい。こうした文脈でカルペンティエルがく脱人間化＞論 を熱烈に支持しながらも暧昧な留保を残さざるを得なかったのは、オルテガの 理論に内包される先述の反歷史性を感知したからにちがいない。だがここでこ の理論の本質を成す理念、すなわち 文化を方向付けること（dirigir la cultura）が重要な位置を占める。なぜならオルテガにとって文化とは、生に固有 
の価值を発見するための「一定の方向にすきない」からだ27!

文化を方向付けること一方向付けられた文化（1a cultura dirigida）。こ の理念はホセ・アントニオ・マラバールがバロック文化の社会的特徽について 指摘した諸定義のひとつを喚起する28)。文化を方向付けること自体には全体主 義的な䏚㕠の可能性も内在するし、実際こうした論考にみられるオルテガは、 フェリペ・ゴンサーレスや土井たか子が院めば苛々するような保守的な言説に 満ちている。けれどオルテガの思想にとって重要なことは一それは本人には 皮肉なことかもしれない一それら保守的な言説に方向付けられる文化や世界 の理念ではなく、オクタビオ・パスが同察したように、わたしたちが方向を決 めるのに仼念は何の役に立つか、それはいかに使い得るか（para qué ser-

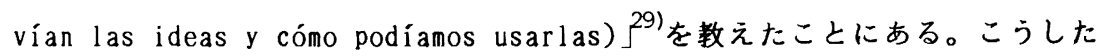
理念の目的性（el para qué）や方法性（el cómo）に関する認識、すなわち文 化を方向付けるための理念への問いは、後年のカルペンティエルに大きな意 味を持っことになった。その最も際立った例は『この世の王国』El reino de este mundo (1949) の序文で表明され、現在もなおカルペンティエル文学の最 大の特徵として言及される、く異的な現実>10 real maravillosoという理 念である。近年の著しい研究の進展によってその虚構性が究め尽くされたこの 理念は30)、オルテガの<脱人間化>論と同じように、理念自体が問われている のではなく、それらの理念によって新しい芸術が方向付けられ、そして文化や 社会 - 更に世界一に異なる可能性を提起することに核心がある。オルテガ の庭には歴史や世界や人間の廆大で複雑な現実は見えないのかもしれないが、 その行為が生成する視線は悹ガラスを意識することで、両者の関係を思考し、 テクストの新しい現実を創造するため、カルペンティエルと同じように、わた したちは庭の理念をつかむことができる。

注

1) José Ortega y Gasset, La Deshumanización del Arte, en Obras Completas 3, Madrid, Alianza/Revista de Occidente, 1983, pp. 357-358. 
2）この論考の文学史的な位置付けについては次を参照。Gerald G. Brown, Historia de la literatura española 6; El siglo XX, Barcelona, Ariel, 1981, pp. $36-38$.

3) op. cit., p. 357 .

4) Leon Livingston, "Ortega y Gasset's Philosophy of Art", PMLA 67 (1952), pp.609-654.

5）Ibíd.. 特に冒頭の部分を参照。

6) La Deshumanización del Arte, op.cit., p 368.

7）これらの議論の詳細は以下を参照。Julián Marías, Ortega. Circunstancia y vocación, Madrid, Alianza, 1983 における “Teoría de la realidad". pp. 408-426.

8） 1. 芸術の脱人間化。2. 生の形象の忌辟。3. 芸術を芸術たらし めること。 4. 芸術の遊戯化。 5. アイロニーの不可欠。 6 . 作りごと の排除、故に周到な創作努勢。7. 整み（intranscendencia）。

9）特に最後の二章（「新しい兆候」「視点の理論」）は <脱人間化 > 論に 至る段階として重要である。

10) La Deshumanización del Arte, op. cit., p.366

11) Gustavo Pérez Firmat, Idle Fictions: The Hispanic Vanguard Novel, 1926-1934, Durham, Duke University Press, 1982, pp.70-71.

12）オルテガのパースペクティウ論については以下を参照。Julián Marías. “La idea de perspectiva", op. cit., pp.363-376.

13) Ideas sobre la novela, en Obras Completas 3, op. cit., p.411.

14) Pérez Firmat, p.153 の注 5 .

15) Roberto González Echevarría, Alejo Carpentier: The Pilgrim at Home, Ithaca and London, Cornell University Press, 1977, p.53.

16）ゴンサーレス・エチェバリーアはスペイン語世界に脱西洋化の傾向を 導入した要因として、シュペングラーの『西欧の没落』の翻訳とともに、再度 オルテガの作品（特に「さまざまなアトランティス」Las Atlántidas [1924]） とその雑誌の編集方針を指摘している（Ibíd..p.117）。しかしオルテガによ 
る歴史概念の拡大という仮説は、その生理性論やパースペクティウ論が李む相 対性の思考からすれば当然の㷌結ではあるが、「自民族中心主義の否定」を尃 く概念ではなかったと考えるべきであろう。

17) Alejo Carpentier, "Ortega y Gasset”, en Roberto González Echevarría, Isla a su vuelo fugitiva, Madrid, José Porrúa Turanzas, 1983. pp.222-224。なおこの小文はオルテガ死去に際して物した追淖文で、初出はカ ラカスの新聞『エル・ナシオナル」1955年10月20日付である。

18) Paul llie, "Benjamín Jarnés: Aspects of the dehumanized novel," PMLA 76 (1961), p. 247.

19) Pérez Firmat, op. cit., pp. 121-137; Robert C. Spires, Beyond the Metafictional Mode, Kentucky. The University Press of Kentucky, 1984, pp.45-57. 以後の引用はこれらの部分による。なお全く不本意ながら、この作 品は遂に実見に至らなかった。

20）この小説は一九二七年に反独裁運動に連座して入鰠中に草稿が成立し、 翌年の渡仏後に補筆されてマドリードで出版された。

21) Frank Janney, Alejo Carpentier and his early works, London, Tamesis, 1981，p.37。この作品については pp.33-68において綿密な読解を展 開している。

22) Roberto González Echevarría, “Borges, Carpentier y Ortega: dos textos olvidados," en Isla a su vuelo fugitiva, op. cit.. pp.217-225.

23) Alejo Carpentier. "En la extrema avanzada. Algunas actitudes del 《surrealismo》, en Obras Completas IX, México, Siglo XXI, 1986, p.126. 初出は『ソシアル』誌 1928年12月号である。

24) Alejo Carpentier: The Pilgrim at Home, p.68 における ゴンサーレ ス・エチェパリーアによる引用。

25）「現象学的還元」については、フッサール、「イデーンIー1」渡刃二郎 訳、みすず書房、昭和六十年、第一巻第二篇第四章でその過程が詳細に論じら れているが、より凝縮した形では同第一篇第二章第三十三節 末尾（邦訳 pp. 148-150）で予備的に考察される。 
26) Terry Eagleton, Literary Theory. An introduction, 0xford, Basil Blackwell，1983，p.61。邦訳は大橋洋一（「文学とは何か小岩波春店、昭和 六十年、p.97）による。

27) El tema de nuestro tiempo, en Obras Completas 3. p.190.この「生

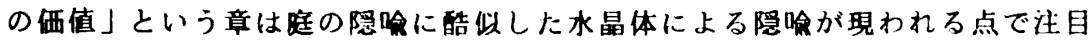
に值する。

28) José Antonio Maravall, La cultura del Barroco, Barcelona, Ariel. 1983（初版 1975），pp.131-175。この章に付された题名は“Una cultura di rigida"という。

29) Octavio Paz. "José 0rtega y Gasset: el cómo y el para qué." en Honbres en su siglo, Barcelona, Seix Barral, 1984, p.103.

30) González Echevarría. The Pilgri at Home, pp.107-129 や Janney. pp.9-10 でも詥及されているが、この問題の最高の研究はIrlemar Chiampi. El realismo naravilloso, Caracas, Monte Avila, 1983 であろう。 


\title{
LA IDEA DEL JARDIN --- ENSAYO ACERCA DE LA INFLUENCIA DEL PENSAMIENTO DE ORTEGA Y GASSET EN ALEJO CARPENTIER
}

\author{
por Tsutomu SUGIURA
}

En su famoso ensayo "La Deshumanización del Arte," afirma Ortega y Gasset que la obra de arte debe separarse de la realidad humana, y que, por tanto, el arte nuevo no debe preocuparse por la realidad concreta de la vida que es el mundo vivido, sino por el texto que es la obra de arte. Esta idea, que él expresaba como "deshumanización," aparece, simbólicamente encarnada, en la imagen del jardin y el vidrio: la mirada debe dirigirse al vidrio de la ventana más bien que al jardin. Esta imagen metaforica es importante por tres razones. En primer lugar, porque presupone la separación definitiva entre el jardin (realidad) y el vidrio (texto). El sujeto individual no debe tomar como objeto la realidad misma, sino la idea que formamos de la realidad. Segundo, porque la idea de que el punto de vista causa necesariamente la separación de dos objetos, y la de la perspectiva por la que se entiende la realidad, conducen a la subjetivización del punto de vista y a la autoreferencialidad del texto. $Y$, en tercer lugar, porque la imagen del jardin, tan preferida por Ortega, no es una mera metáfora sino la realidad, "puesta entre paréntesis," resultante de la "reducción fenomenologica" a que lleva la fenomenologia de Husserl, filosofo que ejerció una poderosa influencia sobre el pensamiento de Ortega en aquel entonces.

Aunque es cierto que la teorla estética, en general, de ortega y la "Revista de Occidente" por él fundada, tuvieron una enorme influencia en los artistas jóvenes de España y la Améri- 
ca Española, se limitó a las orientaciones culturales y artisticas. Si comparamos las obras contemporáneas del escritor español, Benjamén Jarnés, que recibio una gran influencia de la teorla de Ortega, y las del escritor cubano, Alejo Carpentier, en su primera etapa, veremos que la obra de Jarnés posee caracteres de metaficción -ficción respecto a la ficcionalidad del texto-, como resultado de prácticas novelisticas bastante fieles a la teorfa de la "deshumanización," mientras que Alejo Carpentier, en su obra, se propone la fusión entre el texto literario y la realidad histórica del Caribe, basándose en un concepto de cultura a partir del movimiento afrocubano y, por tanto, contradice, evidentemente, la "deshumanización." Además, Alejo Carpentier, manifestó un apoyo entusiasta y, al mosmo tiempo, cierta repulsión contra esa teorfa.

Al ser fruto de una operación fenomenológica, la idea del jardin es esencialmente antihistórica, y no podfa ser compatible con la problemática artistica del joven Carpentier. Pero el autor cubano aprendió de Ortega la importancia de las ideas en el aspecto de dirigir la cultura. $Y$ es que el núcleo del pensamiento de Ortega no está en las ideas hacia las que se orientan sus discursos en torno a la cultura o el mundo, sino en el "para qué" servir y el "cómo" usarse esas ideas con el fin de dar una orientación cultural. Consciente del carácter orientador de las ideas señalado por Ortega, Carpentier reconoce el significado que encierran las ideas que propone su pensamiento en la orientación del quehacer cultural, como es obvio en el caso del planteamiento de su famosa aserción de "lo real maravilloso." 